\title{
Posterior Instrumentation for Occipitocervical Fusion
}

\author{
George Sapkas ${ }^{1}$, Stamatios A. Papadakis ${ }^{*}, 2$, Dimitrios Segkos ${ }^{2}$, Konstantinos Kateros $^{3}$, \\ George Tsakotos ${ }^{2}$ and Pavlos Katonis ${ }^{4}$
}

\author{
${ }^{I}$ A' Department of Orthopaedics, Medical School of Athens University, "Attikon" University Hospital, Haidari, Greece \\ ${ }^{2} D$ ' Department of Orthopaedics, "KAT" General Hospital, Kifissia, Greece \\ ${ }^{3}$ Department of Orthopaedics, "G. Gennimatas" General Hospital, Athens, Greece \\ ${ }^{4}$ Department of Orthopaedics, Medical School of Herakleion University, Crete, Greece
}

\begin{abstract}
Since 1995, 29 consecutive patients with craniocervical spine instability due to several pathologies were managed with posterior occipitocervical instrumentation and fusion. Laminectomy was additionally performed in nineteen patients. The patients were divided in two groups: Group A which included patients managed with screw-rod instrumentation, and Group B which included patients managed with hook-and-screw-rod instrumentation. The patients were evaluated clinically and radiographically using the following parameters: spine anatomy and reconstruction, sagittal profile, neurologic status, functional level, pain relief, complications and status of arthrodesis. The follow-up was performed immediately postoperatively and at 2, 6, 12 months after surgery, and thereafter once a year. Fusion was achieved in all but one patient. One case of infection was the only surgery related complication. Neurological improvement and considerable pain relief occurred in the majority of patients postoperatively. There were neither intraoperative complications nor surgery related deaths. However, the overall death rate was $37.5 \%$ in group A, and $7.7 \%$ in group B. There were no instrument related failures. The reduction level was acceptable and was maintained until the latest follow-up in all of the patients. No statistical difference between the outcomes of screw-rod and hook-and-screw-rod instrumentation was detected. Laminectomy did not influence the outcome in either group. Screw-rod and hook-andscrew-rod occipitocervical fusion instrumentations are both considered as safe and effective methods of treatment of craniocervical instability.
\end{abstract}

Keywords: Occipitocervical fusion, craniocervical instability, spine, reconstruction, posterior procedures.

\section{INTRODUCTION}

The occipitocervical joint consists of the occiput, atlas, and axis and contributes more than $50 \%$ of the rotation and flexion-extension of the head and neck [1]. A wide variety of abnormalities affect the occipitocervical junction causing instability of the occipitocervical junction, which finally leads to neural compression and/or craniospinal, or spinal instability [2-8]. Whatever the pathological process might be, it demands especially if it is symptomatic and progressive, immediate correction of subluxation or malalignment, decompression, and stabilization.

The majority of occipitocervical lesions are anterior and anterolateral. Posterior surgical decompression remains invaluable for the treatment of these lesions in select cases, as well as the posteriorly situated lesions. Reduction surgery and internal fixation are chosen when positioning or traction alone are adequate for the realigning of the column, but irreducible deformities need additional decompressive surgery using an anterior/transoral or posterior approach depending on the site of compression $[7,9,10]$.

*Address correspondence to this author at the $28^{\text {th }}$ Octovriou Str. 54,15236 N. Pendeli, Greece; Tel: +30 6944 297086; Fax: +30 2106137 145;

E-mail: snapmd@gmail.com
Occipitoatlantoaxial instability due to RA, trauma, neoplasms, dens dysplasias or os odontoideum, Down syndrome $[3,5-9,11]$, and occasionally a prior failed attempt at C1-2 fusion or a complex cervical deformity [12], are the commonest indications for occipitocervical fusions.

The purpose of this study is to report the use of occipitocervical fusion instrumentations in the craniocervical joint of 29 patients suffering from several diseases in order to investigate the versatility and the usefulness of the systems. Specifically, the operated patients were examined for neurologic status improvement, fusion rate, pain relief, and complications after using the fixation techniques.

\section{MATERIALS AND METHODOLOGY}

Twenty-nine consecutive patients with acute and chronic spinal lesions (Table 1) located in the region from $\mathrm{Cl}$ to $\mathrm{C} 5$ were managed by using either a hookand-screw-rod system [posterior cervical Compact Cotrel Dubousset system (CCD) (Medtronic Sofamor Danek, USA)] or a screw-rod system [PCR Summit (DePuy Orthopaedics, Inc, USA) or the similar Vertex (Medtronic Sofamor Danek, USA)] for occipitocervical fusion in two affiliated academic spine units between 1995 and 2003, using the same surgical technique and evaluation protocol approved by the scientific committees with which the principal investigators are affiliated. The 
Table 1. Patients Profile Pre- and Postoperatively

GROUP A

Subgroup A1

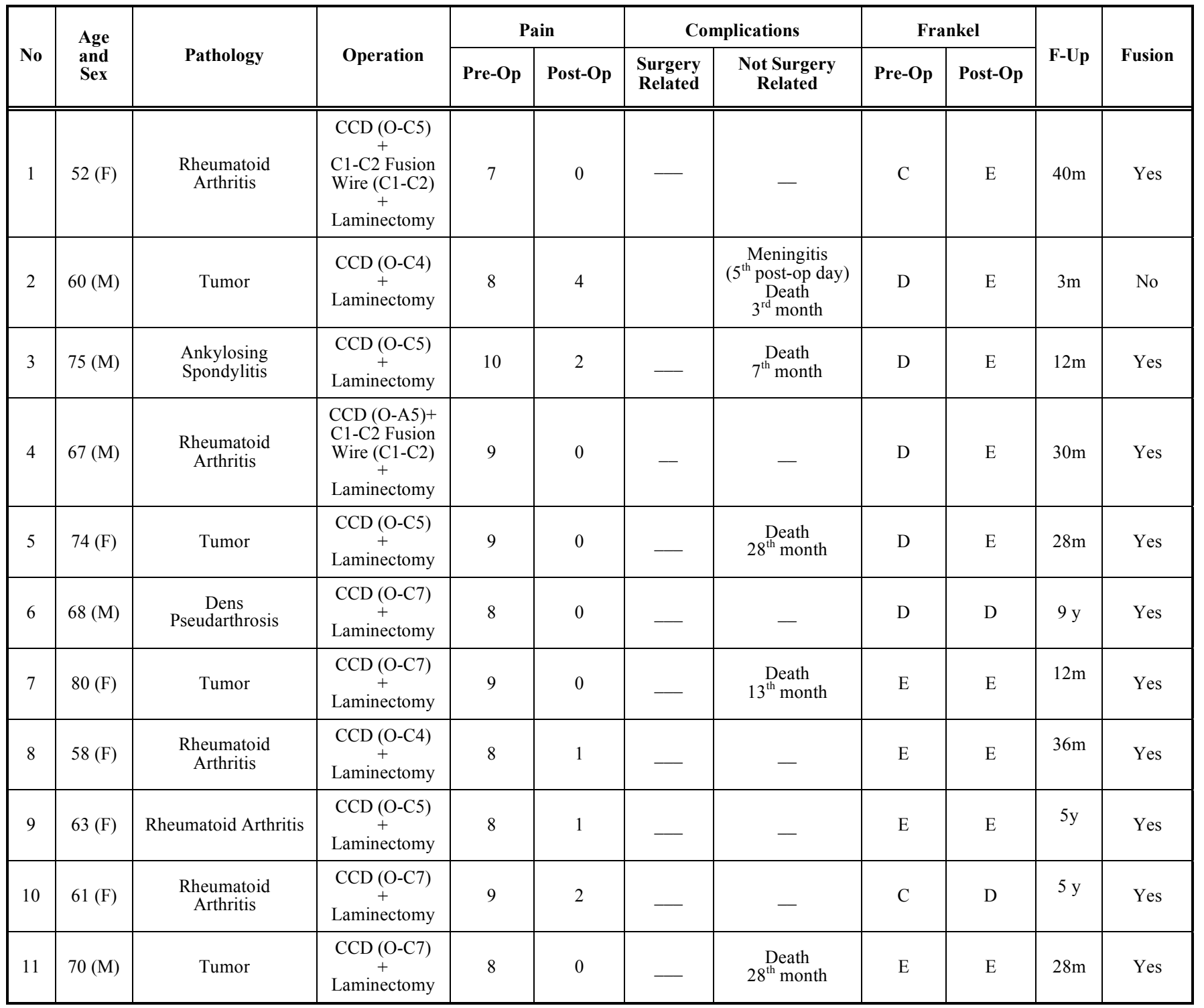

Subgroup A2

\begin{tabular}{|c|c|c|c|c|c|c|c|c|c|c|c|}
\hline \multirow[b]{2}{*}{ No } & \multirow{2}{*}{$\begin{array}{l}\text { Age } \\
\text { and } \\
\text { Sex }\end{array}$} & \multirow[b]{2}{*}{ Pathology } & \multirow[b]{2}{*}{ Operation } & \multicolumn{2}{|c|}{ Pain } & \multicolumn{2}{|c|}{ Complications } & \multicolumn{2}{|c|}{ Frankel } & \multirow[b]{2}{*}{ F-Up } & \multirow[b]{2}{*}{ Fusion } \\
\hline & & & & Pre-Op & Post-Op & $\begin{array}{l}\text { Surgery } \\
\text { Related }\end{array}$ & $\begin{array}{c}\text { Not Surgery } \\
\text { Related }\end{array}$ & Pre-Op & $\begin{array}{c}\text { Post- } \\
\text { Op }\end{array}$ & & \\
\hline 1 & $40(\mathrm{~F})$ & Trauma & $\mathrm{CCD}(\mathrm{O}-\mathrm{C} 4)$ & 9 & 0 & - & - & $\mathrm{E}$ & $\mathrm{E}$ & $36 \mathrm{~m}$ & Yes \\
\hline 2 & $70(\mathrm{M})$ & $\begin{array}{l}\text { Ankylosing } \\
\text { Spondylitis }\end{array}$ & $\mathrm{CCD}(\mathrm{O}-\mathrm{C} 5)$ & 10 & 2 & - & - & D & $\mathrm{E}$ & $38 \mathrm{~m}$ & Yes \\
\hline 3 & $52(\mathrm{~F})$ & $\begin{array}{l}\text { Rheumatoid } \\
\text { Arthritis }\end{array}$ & $\mathrm{CCD}(\mathrm{O}-\mathrm{C} 6)$ & 6 & 1 & - & - & $\mathrm{E}$ & E & $36 \mathrm{~m}$ & Yes \\
\hline 4 & $71(\mathrm{~F})$ & $\begin{array}{c}\text { Cervical } \\
\text { Spondylosis }\end{array}$ & $\mathrm{CCD}(\mathrm{O}-\mathrm{C} 4)$ & 10 & 1 & - & - & $\mathrm{D}$ & $\mathrm{E}$ & $28 \mathrm{~m}$ & Yes \\
\hline 5 & $57(\mathrm{M})$ & Tumor & $\begin{array}{c}\mathrm{CCD}(\mathrm{O}-\mathrm{C} 6) \\
+ \\
\text { Cage } \\
+ \\
\text { ORION plate } \\
+ \\
\text { Anterior procedure }\end{array}$ & 9 & 8 & $\begin{array}{l}\text { Posterior } \\
\text { Fusion } \\
\text { Infection }\end{array}$ & $\begin{array}{c}\text { Death } \\
18^{\mathrm{th}} \text { month }\end{array}$ & $\mathrm{D}$ & $\mathrm{D}$ & $18 \mathrm{~m}$ & No \\
\hline
\end{tabular}


(Table 1) contd.....

GROUP B

Subgroup B1

\begin{tabular}{|c|c|c|c|c|c|c|c|c|c|c|c|}
\hline \multirow{2}{*}{ No } & \multirow{2}{*}{$\begin{array}{l}\text { Age } \\
\text { and } \\
\text { Sex }\end{array}$} & \multirow{2}{*}{ Pathology } & \multirow{2}{*}{ Operation } & \multicolumn{2}{|c|}{ Pain } & \multicolumn{2}{|c|}{ Complications } & \multicolumn{2}{|c|}{ Frankel } & \multirow{2}{*}{ F-Up } & \multirow{2}{*}{ Fusion } \\
\hline & & & & Pre-Op & Post-Op & $\begin{array}{l}\text { Surgery } \\
\text { Related }\end{array}$ & $\begin{array}{l}\text { Not Surgery } \\
\text { Related }\end{array}$ & Pre-Op & $\begin{array}{l}\text { Post- } \\
\text { Op }\end{array}$ & & \\
\hline 1 & $77(\mathrm{M})$ & Trauma & $\begin{array}{c}\text { PCR Summit (O- } \\
\text { C4) } \\
+ \\
\text { C1-C2 Fusion } \\
\text { Wire (C1-C2) } \\
+ \\
\text { Laminectomy }\end{array}$ & 9 & 1 & - & - & E & E & $36 \mathrm{~m}$ & Yes \\
\hline 2 & $69(\mathrm{~F})$ & $\begin{array}{l}\text { Rheumatoid } \\
\text { Arthritis }\end{array}$ & $\begin{array}{c}\text { VERTEX } \\
\text { (O-C4) } \\
+ \\
\text { Laminectomy }\end{array}$ & 9 & 0 & - & - & $\mathrm{D}$ & E & $30 \mathrm{~m}$ & Yes \\
\hline 3 & $75(\mathrm{~F})$ & Tumor & $\begin{array}{c}\text { VERTEX } \\
(\mathrm{O}-\mathrm{C} 5) \\
+ \\
\text { Laminectomy }\end{array}$ & 9 & 0 & 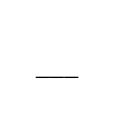 & - & $\mathrm{E}$ & E & $24 \mathrm{~m}$ & Yes \\
\hline 4 & $70(\mathrm{~F})$ & $\begin{array}{l}\text { Rheumatoid } \\
\text { Arthritis }\end{array}$ & $\begin{array}{c}\text { VERTEX } \\
(\mathrm{O}-\mathrm{C} 7) \\
+ \\
\text { C1-C2 Fusion } \\
\text { Wire (C1-C2) } \\
+ \\
\text { Laminectomy }\end{array}$ & 7 & 1 & - & - & $\mathrm{D}$ & $\mathrm{D}$ & $18 \mathrm{~m}$ & Yes \\
\hline 5 & $64(\mathrm{~F})$ & $\begin{array}{c}\text { Dens } \\
\text { Pseudarthrosis }\end{array}$ & $\begin{array}{c}\text { VERTEX } \\
(\mathrm{O}-\mathrm{C} 4) \\
+ \\
\text { Laminectomy }\end{array}$ & 8 & 0 & - & - & E & E & $15 \mathrm{~m}$ & Yes \\
\hline 6 & $65(\mathrm{M})$ & Trauma & $\begin{array}{c}\text { VERTEX } \\
\text { (O-C6) } \\
+ \\
\text { Laminectomy }\end{array}$ & 8 & 1 & - & - & A & A & $12 \mathrm{~m}$ & Yes \\
\hline 7 & $78(\mathrm{M})$ & Tumor & $\begin{array}{c}\text { VERTEX } \\
\text { (O-C6) } \\
+ \\
\text { Laminectomy }\end{array}$ & 9 & 0 & - & - & E & E & $9 \mathrm{~m}$ & Yes \\
\hline 8 & $75(\mathrm{M})$ & Tumor & $\begin{array}{c}\text { VERTEX } \\
\text { (O-C6) } \\
+ \\
\text { Laminectomy } \\
+ \\
\text { Anterior } \\
\text { procedure }\end{array}$ & 9 & 0 & - & - & $\mathrm{D}$ & E & $6 \mathrm{~m}$ & Yes \\
\hline
\end{tabular}

Subgroup B2

\begin{tabular}{|c|c|c|c|c|c|c|c|c|c|c|c|}
\hline No & $\begin{array}{l}\text { Age } \\
\text { and } \\
\text { Sex }\end{array}$ & Pathology & Operation & \multicolumn{2}{|c|}{ Pain } & \multicolumn{2}{|c|}{ Complications } & \multicolumn{2}{|c|}{ Frankel } & F-Up & Fusion \\
\hline 2 & $80(\mathrm{~F})$ & Tumor & $\begin{array}{l}\text { PCR Summit } \\
\text { (O-C7) }\end{array}$ & 8 & 0 & - & - & $\mathrm{C}$ & $\mathrm{D}$ & $36 \mathrm{~m}$ & Yes \\
\hline 4 & $70(\mathrm{M})$ & $\begin{array}{l}\text { A1-A2 } \\
\text { Infection }\end{array}$ & $\begin{array}{c}\text { PCR Summit } \\
\text { (O-C5) } \\
+ \\
\text { Anterior } \\
\text { Procedure }\end{array}$ & 10 & 0 & - & - & B & $\mathrm{D}$ & $6 \mathrm{~m}$ & Yes \\
\hline 5 & $66(F)$ & Tumor & $\begin{array}{c}\text { VERTEX } \\
(\mathrm{O}-\mathrm{T} 2) \\
+ \\
\text { VARIGRIP } \\
+ \\
\text { Kyphoplasty }\end{array}$ & 9 & 0 & - & $\begin{array}{c}\text { Death } \\
12^{\text {th }} \text { month }\end{array}$ & $\mathrm{D}$ & $\mathrm{E}$ & $12 \mathrm{~m}$ & Yes \\
\hline
\end{tabular}


choice of instrumentation either screw-rod or screwand-hook-rod was randomized. The occipitocervical fusion was combined with laminectomy in nineteen cases, with Brooks-Gallie technique of fusion in two cases, and an anterior procedure in three cases. Grafts (Allomatrix) were applied in most of the cases. Bone cement was applied in some cases with very poor bone stock, especially in tumors and severe rheumatoid arthritis. The occipital screws were placed at the centre of the posterior inferior occipital bone which is thick and mainly consists of dense cortical bone. Computer assisted navigation was not used in our series. Postoperatively the stabilization was in every case (so that the study would be unbiased as to the postoperative use of orthoses) secured with a Halo-jacket for at least 3 months and a Philadelphia collar for an additional 3-month period in order to augment fusion which was to our opinion especially necessary in cases of tumor or very poor bone stock.

The indications for surgery were acute or chronic instability, presence of neurologic deficit, and resistant pain. The pathology of each case is shown in Table 1. There were 14 men and 15 women, and their average age was 65 years (range, 30-80 years). Eleven patients suffered from chronic cervical spine diseases (rheumatoid arthritis, ankylosing spondylitis, cervical degeneration) (Fig. 1), 11 patients of tumor of the cervical spine (Fig. 2), 3 of fresh traumatic lesion of the cervical spine, and two of dens pseutharthrosis. In all of the patients, fusion involved the occipitocervical junction. The patients were clinically and radiologically re-evaluated immediately postoperatively and also at 2 , 6 and 12 months after surgery, and thereafter once a year. Clinical evaluation consisted of the neurological and functional status, and also pain improvement. The neurological and functional statuses were estimated using the Frankel classification; patients preoperatively classified as A (whose status was unlikely to improve) or B-C-D (whose status could either deteriorate or improve or remain unchanged) or E (whose status could either deteriorate or remain unchanged) were studied separately. Pain was subjectively estimated by the following method: the patient chose a number between 0 and 10 that best fitted to the pain status considering 0 as no pain at all, 1 as the mildest possible pain, and 10 as the worst possible pain. Radiological evaluation for the diagnosis of the underlying cause and the follow-up comprised plain and flexion/extension roentgenograms and CT scans; since 1999 MRI was also performed routinely in every patient for the diagnosis and the follow-up.

Patients were divided into two groups: Group A which included patients treated with CCD system, and Group B which included patients treated with PCR or Vertex systems. Groups A and B were each subdivided into two subgroups: $\mathrm{A} 1 / \mathrm{A} 2$ and $\mathrm{B} 1 / \mathrm{B} 2$ respectively; groups $\mathrm{A} 1$ and $\mathrm{B} 1$ included patients who had undergone laminectomy, and groups A2 and B2 included patients who had not undergone laminectomy (Table 1). The data collection of the two groups was completed at 12 months follow up and it was statistically evaluated.
Student "t-test" was used to evaluate any statistical difference as to the postoperative improvement/deterioration of pain and neurological status, whereas $x^{2}$ with Yates correction was used to estimate any statistical difference as to the reoperation rate and the fusion rate. Statistical significance was set at $\mathrm{p}<0.05$.

\section{Surgical Procedure}

In all patients with dislocation, reduction was achieved by halo traction. After intubation, patients were placed prone on a frame and a horseshoe-type head holder or halo traction device. Correct cervical alignment was established under fluoroscopy. The head was taped to the head holder, and the shoulders were pulled caudal by a heavy bandage. During these maneuvers the cervical spine was strictly maintained in a neutral position. With a median skin incision, the paravertebral muscles were dissected laterally to expose the occipitocervical junction, the laminae and the articular masses in the upper cervical vertebrae. The skull was subperiosteally prepared up to the occipital notch. Then the occipitocervical instrumentation was applied. In all patients potentials were checked prior to anaesthesia, after anaesthesia and prior to the rolling of the patient, and after the rolling of the patient. Intraoperative monitoring was performed routinely since 2000; before 2000, a wake-up test was performed. Unless impaired neurologically or by their general condition the patients were encouraged to ambulate or sit up on the bed the day after surgery.

\section{RESULTS}

Group A: There was no intraoperative complication. Infection in one patient was the only surgery related postoperative complication (infection rate $6.1 \%$ ). Among the sixteen patients, six died during the follow-up (death rate $37.5 \%$ ). None of the deaths was surgery related: four patients died due to a neoplasm, one patient with ankylosing spondylitis died to a heart attack 7 months postoperatively, and, finally, one death happened at the early postoperative period ( $<3$ months) due to a brain stroke that complicated meningitis related to the neurosurgical operation that was performed prior to the orthopaedic operation (intracanal tumor resection) that was performed by a neurosurgeon just prior to the orthopaedic stabilization performed by an orthopaedic surgeon.

Among the fifteen patients that survived more than 3 months a solid fusion was achieved in all but one patient (fusion was not achieved in this patient because an infection occurred) (fusion rate: $93.75 \%$ ). The pain, on a scale of $0-10$, improved in all patients treated with CCD (including the one in which an infection occurred) by an average of 7.4 grades (range, 1-9), but excluding the patient with infection and the patient who survived less than 3 months the pain improved by an average of 7.9 grades (range, 5-9). The neurological status improved in the vast majority of patients with a neurological deficit preoperatively. There was no patient preoperatively classified as Frankel A or B. Eight out of ten preoperatively Frankel C-D patients improved 
(a)

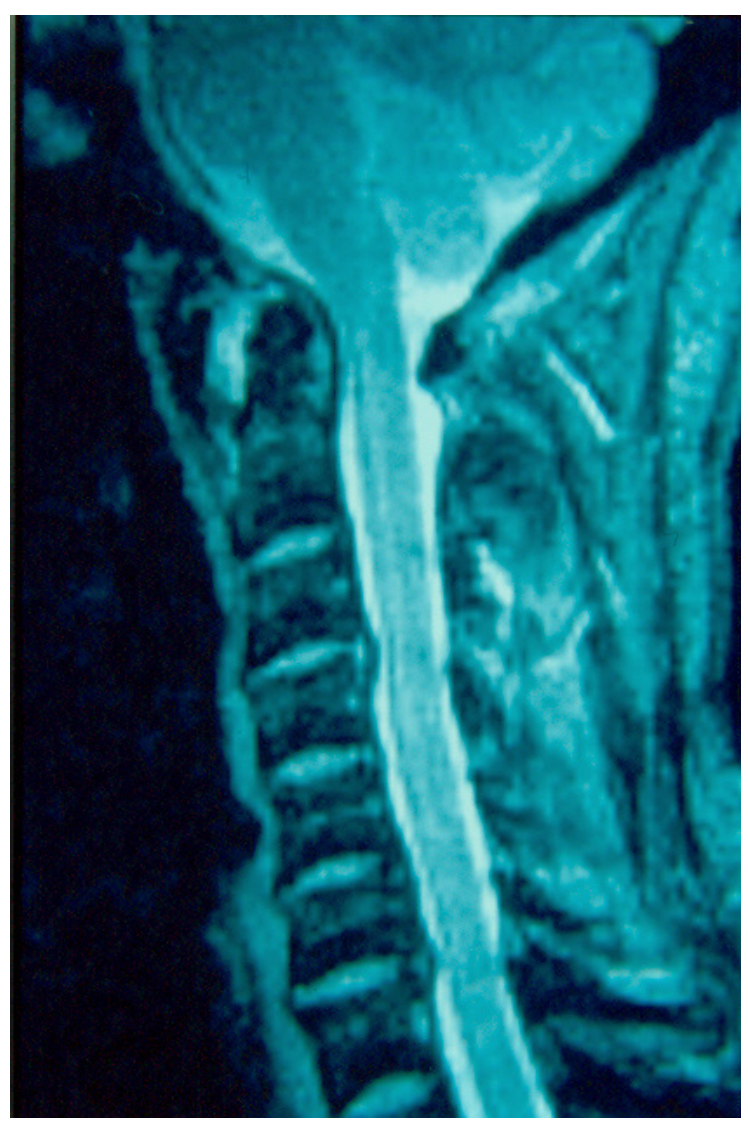

(b)

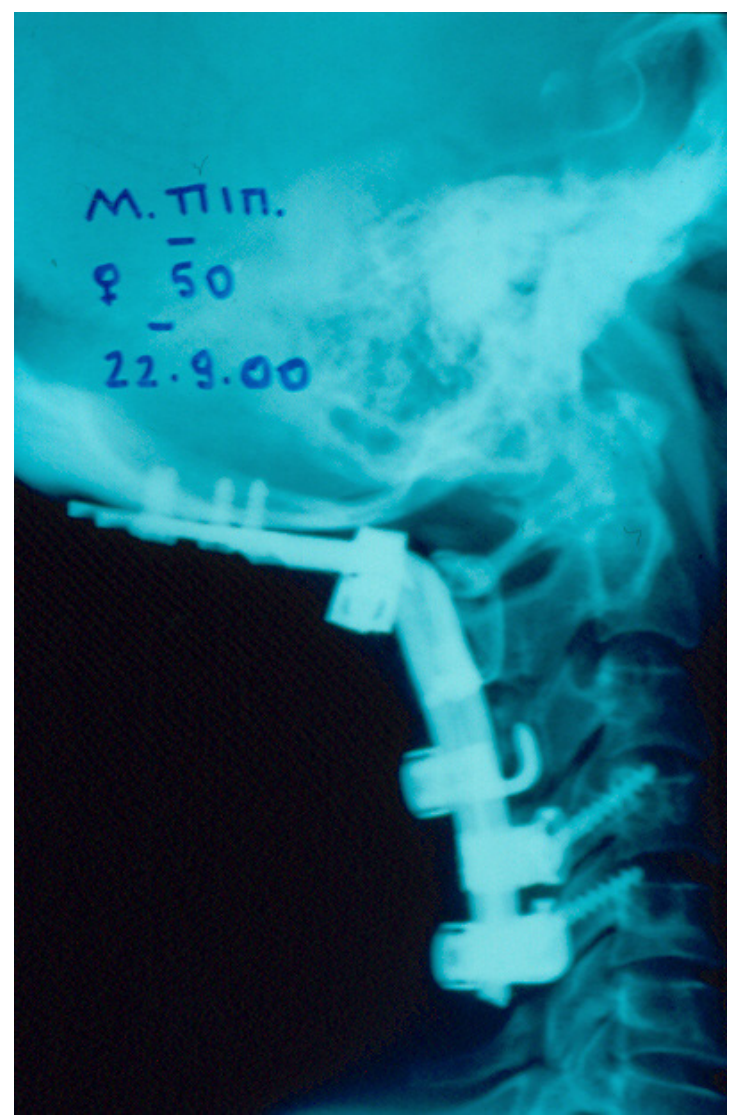

(c)

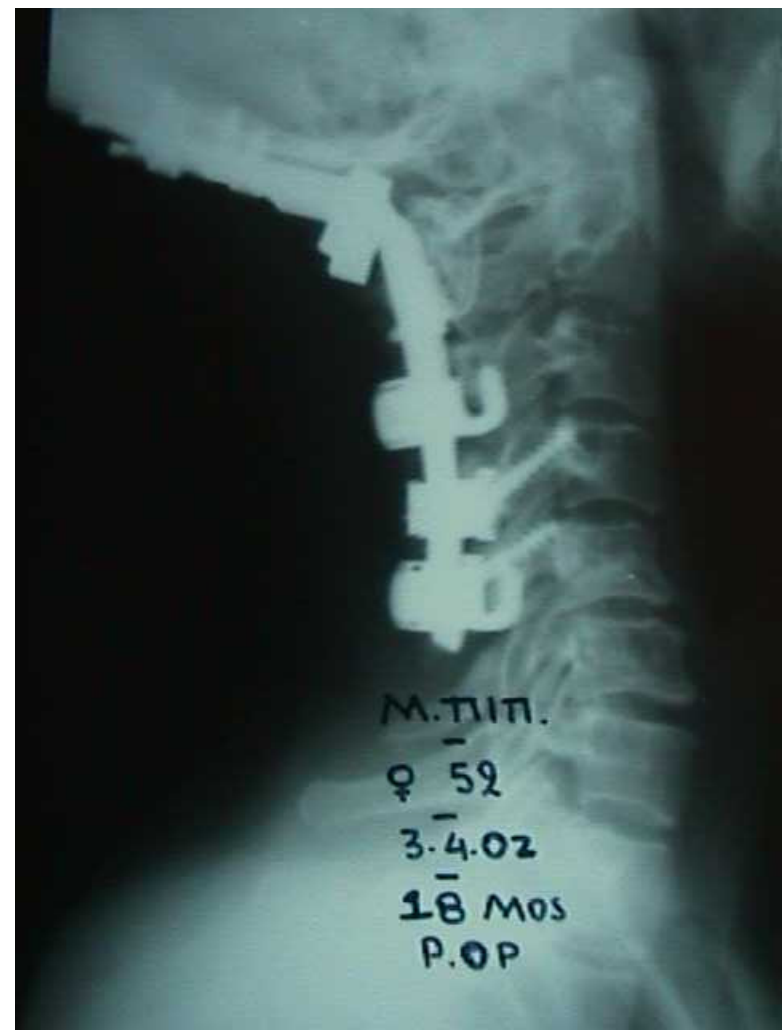

Fig. (1). (a-c) A patient with rheumatoid arthritis (case 4): after the application of a posterior CCD system, the sagittal profile of the cervical spine and the C1-C2 stability was restored and maintained during an 18 months follow-up. (a) MRI scan: C1-2 instability, vasilar invagination, and cord compression are obvious, (b) $2^{\text {nd }}$ post-op day, (c) $18^{\text {th }}$ post-op month. 
(a)

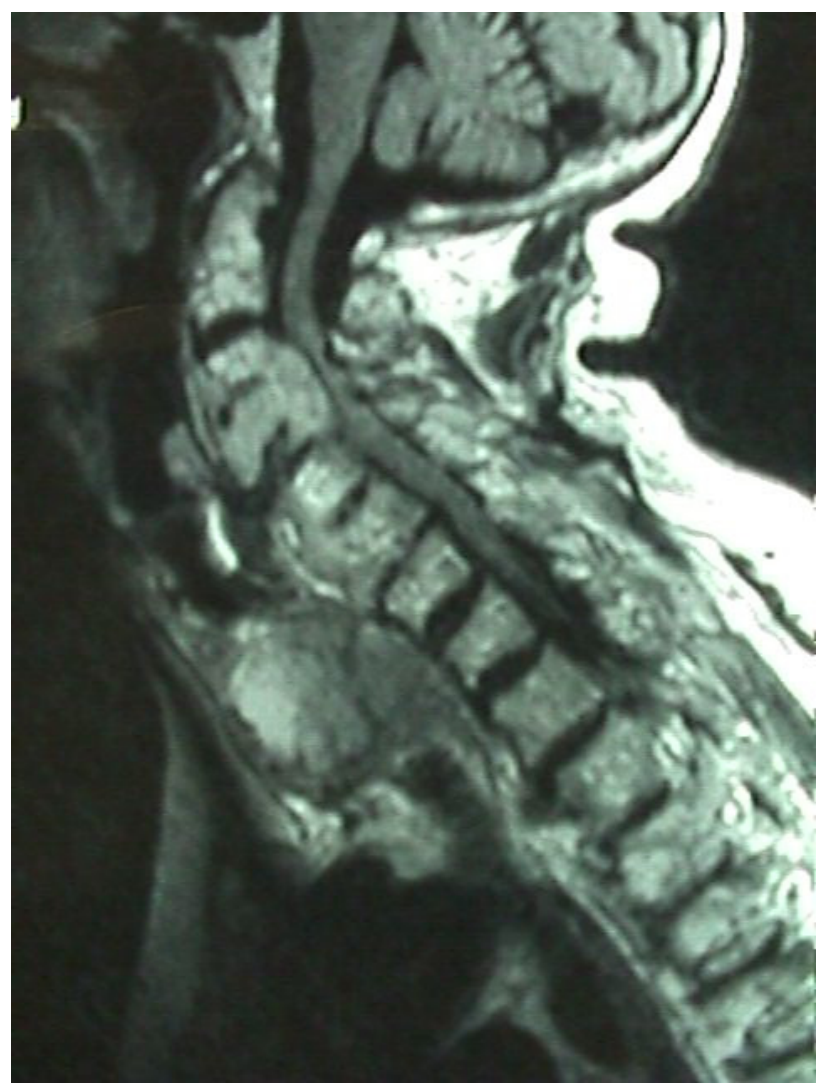

(b)

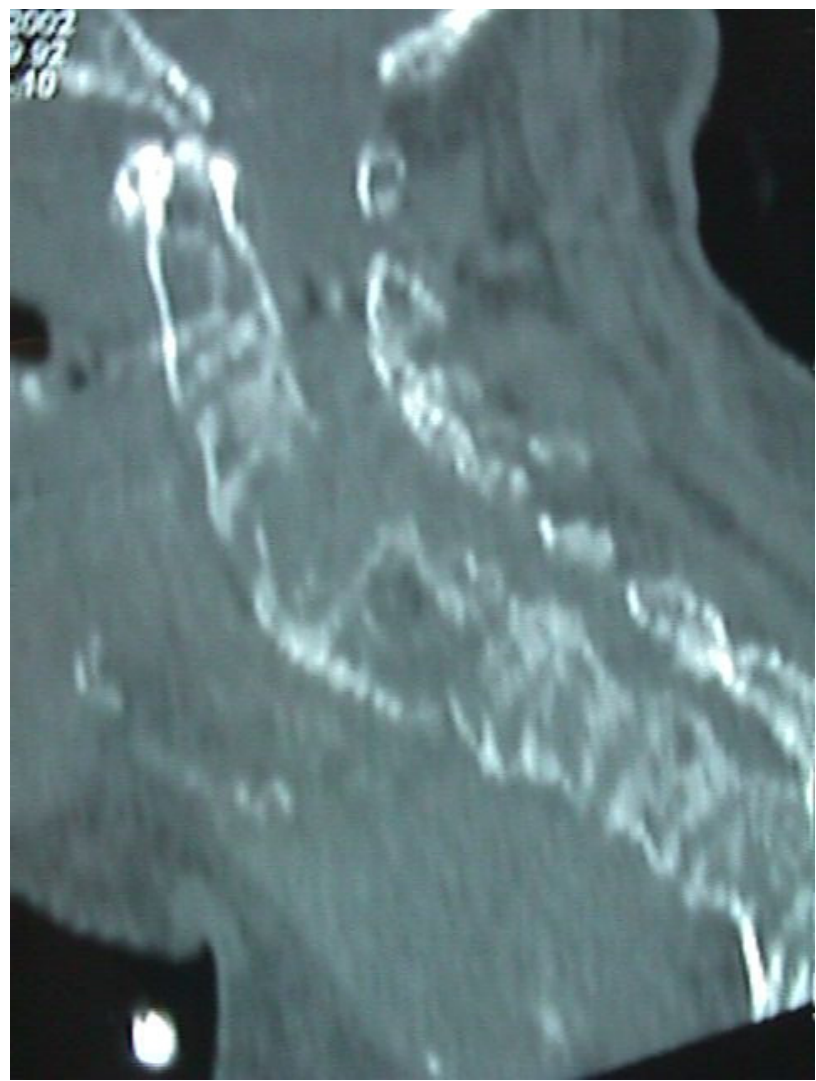

(c)

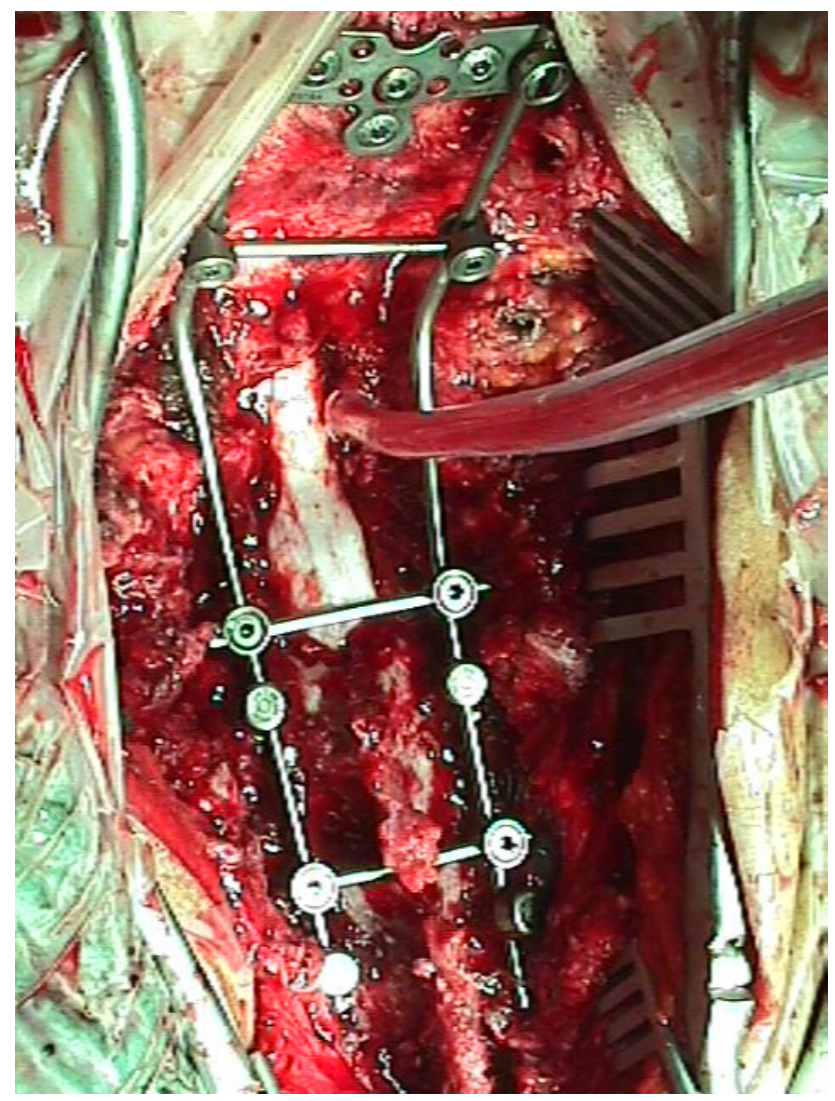

Fig. (2). (a-c) A patient with a metastasis in the cervical spine. (a): MRI showing cord compression. (b): CT scan showing severe osteolysis resulting in C1-2 instability. (c): Laminectomy and application of PCR Summit instrumentation for occipitocervical fusion. 
Table 2. Postoperative Reduction of the Sagittal Profile

\begin{tabular}{|c|c|c|c|c|}
\hline Instrumentation & Parameters & $\begin{array}{c}\text { Preoperatively Mean } \\
\text { (Range) }\end{array}$ & $\begin{array}{c}\text { Postoperatively Mean } \\
\text { (Range) }\end{array}$ & $\begin{array}{c}\text { Follow-Up Mean } \\
\text { (Range) }\end{array}$ \\
\hline \hline \multirow{2}{*}{ Screw-rod system (Group A) } & Occiput-C7 lordosis (degrees) & $-31.1(-13$ to -40$)$ & $-40.7(-37$ to -46$)$ & $-40.3(-34$ to -45$)$ \\
\cline { 2 - 5 } & Vertebral translation (mm) & $1.4(0$ to 2.5$)$ & $0.5(0$ to 1.5$)$ & $0.5(0$ to 1.5$)$ \\
\hline \multirow{2}{*}{ Hook-and-screw-rod system (Group B) } & Occiput-C7 lordosis (degrees) & $-31.4(-11$ to -43$)$ & $-41(-36$ to -45$)$ & $-40.6(-34$ to -44$)$ \\
\cline { 2 - 5 } & Vertebral translation (mm) & $1.3(0$ to 2.5$)$ & $0.4(0$ to 2$)$ & $0.4(0$ to 2$)$ \\
\hline
\end{tabular}

postoperatively by at least one Frankel grade and two patients remained at the same Frankel level (improvement rate $80 \%$ ). The overall improvement of the neurological Frankel status among the preoperatively Frankel C-D patients averaged 0.9 grades. The neurological status did not deteriorate in the six patients with Frankel E level preoperatively.

There was neither hardware failure nor screw loosening until the latest follow-up. The sagittal profile of the occipitocervical junction as shown on the lateral radiographs was reduced after the operation and remained so until the final follow-up in all of the cases (Table 2).

Group B: There was no surgery related (intraoperative or postoperative) complication. The infection rate was $0 \%$. Among the thirteen patients, one died during the follow-up (death rate: $7.7 \%$ ); this death was related to a neoplasm. A solid fusion was achieved in all patients (fusion rate: 100\%). The pain, on a scale of $0-10$, improved in all patients by an average of 8.1 grades (range, 6-10).

The neurological status improved in the vast majority of patients with a neurological deficit preoperatively. One patient, who preoperatively was classified as Frankel A, did not improve postoperatively. Five out of six preoperatively Frankel B-D patients improved postoperatively by at least one Frankel grade, and one patient remained at the same Frankel level (neurological improvement rate $83.5 \%$ ). The overall improvement of the neurological Frankel status among the preoperatively Frankel B-D patients averaged 1 grade. The neurological status did not deteriorate in the six patients with Frankel E level preoperatively.

There was neither hardware failure nor screw loosening until the latest follow-up. The sagittal profile of the occipitocervical junction as shown on the lateral radiographs was reduced after the operation and remained so until the final follow-up in all of the cases (Table 2).

The comparison between the results of the application of hook-and-screw-rod (Group A) and screw-rod (Group B) instrumentation in our study did not reveal any statistically significant difference as to surgery related death rate, infection rate, pain improvement, fusion rate, neurological status improvement, and reduction of sagittal profile.

Laminectomy was not found to influence the outcome of the application of either the hook-and-screw-rod instrumentation (CCD) or the screw-rod instrumentation (PCR or Vertex); no statistically significant difference was detected between groups $\mathrm{A} 1$ and $\mathrm{A} 2$ or between $\mathrm{B} 1$ and $\mathrm{B} 2$ or between all patients with laminectomy (A1 and B1 subgroups) and all patients without laminectomy (A2 and B2 subgroups) (Tables $\mathbf{3}$ and $\mathbf{4}$ ) as to surgery related death rate, infection rate, pain improvement, fusion rate, neurological status improvement, and reduction of sagittal profile.

\section{DISCUSSION}

The cervical spine is unique because of its limited biomechanical strength, the paucity of some osseous structural elements, the neural and vascular structures contained within the spine, the frequent variation in anatomy among patients, and the complexity of the occipitocervical joint. Thus, any instrumentation used in this region should reach particular standards such as mechanical strength in multiple axes (flexion, extension, bilateral lateral bending, bilateral rotation, distraction, and axial loading), high fineness and appropriate dimensions so as to integrate into the cervical spine elements, and great flexibility to allow adjustment to several anatomical variations of this region [13].

Table 3. Results of Subgroups A1, A2, BI, B2, A1+B1, A2+B2. Subgroups A1 and B1 Represent Patients of Groups A and B with Laminectomy. Subgroups A2 and B2 Concern Patients of Groups A and B without Laminectomy

\begin{tabular}{|c|c|c|c|c|}
\hline Subgroups & Pain Improvement Post-Op (Mean Degrees) & $\begin{array}{c}\text { Neurological Status Frankel Classification (Mean) } \\
\text {-Improvement rate: (\%)/ } \\
\text { Grades of Level Improvement }\end{array}$ & Fusion Rate & Infection Rate \\
\hline \hline A1 & 7.6 & $85.7 \% / 1$ & $100 \%$ & $0 \%$ \\
\hline A2 & 6.4 & $67 \% / 0.67$ & $80 \%$ & $100 \%$ \\
\hline B1 & 8.22 & $67 \% / 0.67$ & $100 \%$ & $0 \%$ \\
\hline B2 & 8.4 & $100 \% / 1.34$ & $100 \%$ & $0 \%$ \\
\hline A1+B1 & 7.79 & $80 \% / 0.9$ & $90 \%$ & $10 \%$ \\
\hline A1+B2 & 7.4 & $83.3 \% / 1$ & 9 \\
\hline
\end{tabular}


Table 4a-c.Comparative Analysis of the Postoperative Reduction of the Sagittal Profile Between Patients with and without Laminectomy

a) Comparison Between A1 and A2 Subgroups

\begin{tabular}{|c|c|c|c|c|}
\hline \multirow{2}{*}{ Instrumentation } & Parameters & Preoperatively Mean (Range) & Postoperatively Mean (Range) & Follow-Up Mean (Range) \\
\hline \hline \multirow{2}{*}{ Subgroup A1 } & Occiput-C7 lordosis (degrees) & $-30.7(-13$ to -37$)$ & $-40.3(-37$ to -44$)$ & $-40.4(-35$ to -45$)$ \\
\cline { 2 - 5 } & Vertebral translation (mm) & $1.2(0$ to 2.5$)$ & $0.5(0$ to 1.5$)$ & $0.5(0$ to 1.5$)$ \\
\hline \multirow{2}{*}{ Subgroup A2 } & Occiput-C7 lordosis (degrees) & $-32(-16$ to -40$)$ & $-41.4(-38$ to -46$)$ & $-40(-34$ to -44$)$ \\
\cline { 2 - 6 } & Vertebral translation (mm) & $1.5(0$ to 2.5$)$ & $0.5(0$ to 1.5$)$ & $0.5(0$ to 1.5$)$ \\
\hline
\end{tabular}

b) Comparison Between B1 and B2 Subgroups

\begin{tabular}{|c|c|c|c|c|}
\hline Instrumentation & Parameters & Preoperatively Mean (Range) & Postoperatively Mean (Range) & Follow-Up Mean (Range) \\
\hline \hline \multirow{2}{*}{ Subgroup B1 } & Occiput-C7 lordosis (degrees) & $-31.8(-13$ to -43$)$ & $-41.5(-38$ to -45$)$ & $-41(-36$ to -44$)$ \\
\cline { 2 - 5 } & Vertebral translation (mm) & $1.4(0$ to 2.5$)$ & $0.4(0$ to 2$)$ & $0.4(0$ to 2$)$ \\
\hline \multirow{2}{*}{ Subgroup B2 } & Occiput-C7 lordosis (degrees) & $-30.8(-11$ to -40$)$ & $-40(-36$ to -43$)$ & $-39.5(-34$ to -43$)$ \\
\cline { 2 - 5 } & Vertebral translation $(\mathrm{mm})$ & $1.1(0$ to 2.5$)$ & $0.5(0$ to 2$)$ & $0.5(0$ to 2$)$ \\
\hline
\end{tabular}

c) Comparison Between Patients with Laminectomy (Subgroups A1 and B1) and Patients without Laminectomy (Subgroups A2 and B2)

\begin{tabular}{|c|c|c|c|c|}
\hline Instrumentation & Parameters & Preoperatively Mean (Range) & Postoperatively Mean (Range) & Follow-Up Mean (Range) \\
\hline \hline \multirow{2}{*}{ SubgroupsA1 and B1 } & Occiput-C7 lordosis (degrees) & $-31.2(-13$ to -43$)$ & $-40.8(-37$ to -45$)$ & $-40.6(-35$ to -45$)$ \\
\cline { 2 - 5 } & Vertebral translation (mm) & $1.3(0$ to 2.5$)$ & $0.5(0$ to $)$ & $0.5(0$ to 2$)$ \\
\hline \multirow{2}{*}{ SubgroupsA2 and B2 } & Occiput-C7 lordosis (degrees) & $-31.4(-11$ to -40$)$ & $-40.8(-36$ to -46$)$ & $-39.8(-34$ to -44$)$ \\
\cline { 2 - 5 } & Vertebral translation (mm) & $1.4(0$ to 2.5$)$ & $0.5(0$ to 2$)$ & $0.5(0$ to 2$)$ \\
\hline
\end{tabular}

The first preliminary report on successful use of a screwrod stabilizing system posteriorly applied to the occipitocervical junction was in 1996 by Jeanneret et al. [14].

In the present study, the clinical utility, safety, and effectiveness of hook-and-screw-rod and screw-and-rod instrumentation for posterior craniocervical fixation was demonstrated. The best technique for occipitocervical fusion in case of an unstable craniocervcical junction (CCJ) remains controversial since the desired rigid immediate stabilization demands increasing surgical complexity and risk [15].

Current techniques of posterior occipitocervical fusion include:

Wire fixation-strut bone graft technique: A 98\% fusion rate has been achieved with this technique, despite several biomechanical disadvantages reported $[9,7,11,16]$.

Onlay bone graft technique [17]: Despite its safety [18], the lack of immediate rigid postoperative fixation necessitates prolonged postoperative immobilization.

C1-C2 transarticular screw fixation [19, 20, 21]: A significant range of movement of the cervical spine is maintained when this construct is used, and this is considered to be another advantage in comparison his of to screw-rod or hook-rod occipitocervical fusion systems, since the latter systems lead to considerable cervical spine stiffness which remains even after the hardware removal. However, this method demands high level of expertise and does not lack potential danger of vertebral artery injury and screw malposition [21-23].

Occipitocervical plates and screws: It has been reported to provide very good results [20, 22, 24, 25], even though it is associated with a considerable rate of screw malposition and the danger of vertebral artery injury [25-28].

Contoured rods are another alternative described with a high fusion rate [12, 29, 30-33]. Screw-rod systems appear to offer several advantages compared to screw-plate systems [34]. A study of screw-rod posterior system applied in 30 patients reported good results in all but one patient, and one neurologic deterioration [35]. The use of hook-andscrew-rod system for the treatment of occipitocervical instability is reported to provide stable bony fusion, very low surgery-related morbidity or mortality (0-3\%) and no hardware failure with a $100 \%$ fusion rate [36-39]. In many cases of this series where CCD was applied, a multiple-level fusion was necessary even if the abnormality included one level, because CCD as a hookand-screw-rod system requires the use of the "claw" configuration at the two lowermost levels of fixation, and the avoidance of levels with significant canal stenosis or prior laminectomy is desirable or even demanded. This need for longer instrumentation is the main drawback of CCD when compared with lateral mass screw and pedicular systems $[25,35]$. 
The present study showed that posterior occipitocervical fusion (either with hook-and-screw-rod systems or screw-rod systems) applied in the craniovertebral spine for several abnormalities provided adequate reduction maintaining until the latest observation, and immediate and rigid stabilization of the spine even in cases of instability due to a primary neoplasm or metastasis. Indeed, the heterogeneity in the underlying cause of occipitocervical instability in the patients of our study might make the interpretation of the outcome of occipitocervical fusion difficult. However, our study demonstrated a very good outcome of posterior occipitocervical fusion using either screw-rod or hook-and-screw-rod instrumentation irrespective of the underlying cause; this indicates the versatility of the method which is very important especially in cases of neoplasms or severe degenerative disease.

There was no significant difference between the results of the application of the hook-and-screw-rod and screw-rod system in our series. The fusion rates of both groups (A and B) of our study are comparable to those of the literature. Relief of acute and chronic pain occurred in most of the patients of either group contributing to a considerable improvement to their quality of life. Neurologic improvement and good to excellent functional results in the vast majority of the operated patients of both groups combined with the clinical improvement of the pain confirms the successful use of the two methods.

Although, the death rate in Group A was high, this cannot be attributed to the technique or any other surgery related reason. Four of these deaths were related to the underlying disease which was a malignancy that directly caused the unwanted outcome despite the adequacy of the surgical technique. However, even in these patients surgery proved to be effective as it permitted a considerable pain relief and, therefore, better living conditions.

This finding combined with the very low rate of surgery related complications of this study also confirms the safety of screw-rod and hook-and-screw-rod instrumentation for occipitocervical fusion. Additionally, laminectomy did not influence the outcome of either surgical technique; this might indicate that the stability of occipitocervical fusion is not jeopardized by laminectomy.

In conclusion, occipitocervical fusion with hook-andscrew-rod or screw-rod instrumentation provided good clinical and radiological results in the vast majority of abnormalities of the occipitocervical junction without neurologic, vessel or other major complication. Even though a cohort with mixed diagnoses and constructs was evaluated in our series, it seems that these systems alone or in combination with anterior instrumentation may provide a rigid immediate fixation with very high fusion rate. It is a safe and effective alternative in the management of occipitocervical instability.

\section{REFERENCES}

[1] Vender J, Rekito A, Harrison S, McDonnell D. Evolution of posterior cervical and occipitocervical fusion and instrumentation. Neurosurg Focus 2004; 16: E9.
[2] Crockard HA, Stevens JM. Craniovertebral junction anomalies in inherited disorders. Eur J Paediatr 1995; 154: 504-12.

[3] Crockard HA. Transoral surgery: some lessons learned. $\mathrm{Br} \mathrm{J}$ Neurosurg 1995; 9: 283-93.

[4] Erbengi A, Oge HK. Congenital malformations oh the craniovertebral junction:Classification and surgical treatment. Acta Neurohir (Wien). 1994; 137:180-5.

[5] Menezes AH, Ryken TC. Craniovertebral abnormalities in Down syndromes. Paediatr Neurosurg 1992; 18: 24-33.

[6] Menezes AH, VanGilder AC. In: Youmans J, Becker P, Dunker S, Ed. Abnormalities of the craniovertebral junction. Philadelphia, PA, Saunders 1990; pp. 1350-420.

[7] VanGilder JC, Menezes AH. In: Schmidek HH, Sweet WH, Ed. Craniovertebral abnormalities and their treatment. New York, Grune and Stratton 1982; pp. 1221-35.

[8] VanGilder JC, Menezes AH. In: Wilkins RH, Rengachary SS, Ed. Craniovertebral junction abnormalities. New York, McGraw-Hill. 1985; pp. 2097-01.

[9] Jain VK, Mittal P, Banerji D, Behari S, Acharya R, Chhabra DK. Posterior occipitoaxial fusion for atlantoaxial dislocation associated with occipitalized atlas. J Neurosurg 1996; 84: 559-64.

[10] Menezes AH, Traynelis VC, Gantz BJ. Surgical approaches to craniovertebral junction. Clin Neurosurg 1994; 41: 187-203.

[11] VanGilder JC, Menezes AH. Craniovertebral abnormalities: symptoms, etiology and treatment. Contemp Neurosurg 1981; 3: 16.

[12] Fehlings M, Errico T, Cooper P, Benjamin V, DiBartolo T. Occipitocervical fusion with a five-millimeter malleable rod and segmental fixation. Neurosurgery 1993; 33: 198-208.

[13] Wang MY, Prusmack CJ, Green BA, Gruen JP, Levi AD. Minimally invasive lateral mass screws in the treatment of the cervical facet dislocations: technical note. Neurosurgery $2003 ; 52$ : 444-8.

[14] Jeanneret B. Posterior rod system of the cervical spine: a new implant allowing optimal screw insertion. Eur Spine J 1996; 5: 350-6.

[15] Menezes AH. Complications of surgery at the craniocervical junction-avoidance and management. Pediatr Neurosurg 1991; 17: 254-66.

[16] Rodgers WB, Coran DL, Emans JB, Hresko MT, Hall JE. Occipitocervical fusions in children. Retrospective analysis and technical considerations. Clin Orthop 1999; 364: 125-33.

[17] Newman P, Sweetnam R. Occipito-cervical fusion. An operative technique and its indications. J Bone Joint Surg 1969; 51-B: 42331.

[18] Elia M, Mazzara JT, Fieldinf JW. Onlay technique for occipitocervical fusion. Clin Orthop 1992; 280: 170-4.

[19] Magerl F, Seman PS. In: Kehr P, Ed. Stable posterior fusion of the atlas and axis by transarticular screw fixation. Berlin, Springer. 1987; pp. 322-7.

[20] Grob D, Crisco JJ III, Panjabi MM, Wang P, Dvorak J. Biomechanical evaluation of four different posterior atlantoaxial fixation techniques. Spine 1992; 17: 480-90.

[21] Hanson PB, Montesano PX, Sharkey NA, Raushning W. Anatomic and biomechanical assessment of transarticular screw fixation for atlantoaxial instability. Spine 1991; 16: 1141-5.

[22] Dickman CA, Sonntag VKH. Posterior CI-C2 transarticular screw fixation for atlantoaxial arthrodesis. Neurosurgery 1998; 43: 27581.

[23] Gluf WM, Schmidt MH, Apfelbaum RI. Atlantoaxial transarticular screw fixation: a review of surgical indications, fusion rate, complications, and lessons learned in 191 adult patients. J Neurosurg Spine 2005; 2: 155-63.

[24] Farey ID, Nadkarni S, Smith N. Modified Gallic technique versus transarticular screw fixation in C 1-C2 fusion. Clin Orthop 1999; 359: 126-35.

[25] Sasso RC, Jeanneret B, Fischer K, Magerl F. Occipitocervical fusion with posterior plate and screw instrumentation. A longterm follow-up study. Spine 1994; 15: 2364-8.

[26] Goel A, Karapurkar AP. Transoral plate and screw fixation of the craniovertebral region-a preliminary report. Br J Neurosurg 1994; 8: 743-5.

[27] Grob D, Dvorak J, Panjabi MM, Antinnes JA. The role of plate and screw fixation in occipitocervical fusion in rheumatoid arthritis. Spine 1994; 19: 2545-51. 
[28] Huckell CB, Buchowski JM, Richardson WJ, Williams D, Kostuik JP. Functional outcome of plate fusions for disorders of the occipitocervical junction. Clin Orthop 1999; 359: 136-45.

[29] Abumi K, Takada T, Shono Y, Kaneda K, Fujiya M. Posterior occipitocervical reconstruction using cervical pedicle screws and plate-rod systems. Spine 1999; 24: 1425-34.

[30] Apostolides PJ, Dickman C, Golfinos JG, Papadopoulos SM, Sonntag VK. Threaded steinmann pin fusion of the craniovertebral junction. Spine 1996; 21: 1630-7.

[31] Mitsui H. One-piece cervical device for cervical spine surgery. Spine 1996; 21: 39-44.

[32] Mori T, Matsunaga S, Sunahara N, Sakou T. 3-to-11-year follow up of occipitocervical fusion for reumatoid arthritis. Clin Orthop 1998; 351: 169-79.

[33] Nakagawa T, Yone K, Sakou T, Yanase M. Occipitocervical fusion with C1 laminectomy in children. Spine 1997; 22: 1209-14.
[34] Deen AG, Birch BD, Wharen RE, Reimer R. Lateral mass screwrod fixation of the cervical spine: a prospective clinical series with 1-year follow-up. Spine J 2003; 3: 489-95.

[35] Olerud C, Lind B, Sahlstedt B. The Olerud Cervical Fixation System; a study of safety and efficacy. Ups J Med Sci 1999; 104: 131-43.

[36] Faure A, Bord E, Monteiro da Silva R, Diaz Saldana A, Robert R. Occipitocervical fixation with a single occipital clamp using inverted hooks. Eur Spine J 1998; 7: 80-3.

[37] Heidecke V, Rainov NG, Burkert W. Occipito-cervical fusion with the cervical Cotrel-Dubousset rod system. Acta Neurochir 1998; 140: 969-76.

[38] Korovesis P, Katonis P, Aligizakis $\mathrm{P}$, et al. Posterior compact Cotrel-Dubousset instrumentation for occipitocervical, cervical and cervicothoracic fusion. Eur Spine J 2001; 10: 385-94.

[39] Paquis P, Lonjon M, Grellier P. Craniovertebral stabilization using a new CCD technique. Neurochirurgie 1998; 44: 101-4. 